\title{
Correction methods available for the convicts in Sri Lanka compared with American methods of correction
}

Muditha Vidanapathirana ${ }^{1 *} \otimes(D)$, Rohan P Ruwanpura ${ }^{2}$

${ }^{1}$ Department of Forensic Medicine, Faculty of Medical Sciences, University of Sri Jayewardenepura, Sri Lanka

${ }^{2}$ Office of the Judicial Medical Officer, Teaching Hospital, Karapitiya, Galle, Sri Lanka.

Keywords: Post-conviction corrections, Sri Lanka, USA

Copyright: @ 2018 with the Medico-legal Journal of Sri Lanka.

This is an open-access article distributed under the terms of the Creative Commons Attribution 4.0 International License, which permits unrestricted use, distribution and reproduction in any medium provided the original author and source are credited.

\author{
Funding: None \\ Competing interests: None \\ Received: 22 June 2018
}

*Corresponding author: Vidanapathirana M, Email: mudithavidana@sjp.ac.lk

https://orcid.org/0000-0003-0071-0996

Cite this article as: Vidanapathirana M, Ruwanpura PR. Correction methods available for the convicts in Sri Lanka compared with American methods of correction. Medico-Legal Journal of Sri Lanka, 2018; 6(2): 47-54.

DOI: http://dx.doi.org/10.4038/mljsl.v6i2.7374

\section{Introduction}

Punishment is believed to be an essential feature of civilization. According to philosophical definition, punishment is pain or other unpleasant consequence that results from an offense against a rule and that is administered by others, who represent legal authority, to the offender who broke the rule. ${ }^{[1]}$ The beneficial aspects of punishment include deterrence, incapacitation, and rehabilitation or reform.

Sri Lanka (SL) is governed under the principles and provisions of the constitution and with the executive power, the criminal justice system is executed. In the criminal justice system, the laws are enforced by the police, the suspects are prosecuted by the Attorney General and the punishments are imposed by the judiciary and the punishments are enforced by the correction agencies.

In addition to the national criminal justice system, Islamic community maintains separate punishment and correctional system for minor crimes based on religious Kathi laws that are executed through chief priest of the mosque.

When the post-conviction correction methods are considered, we need to seek what type of methods available in Sri Lanka? How have those methods been introduced to our country? We should also explore how they have contributed to the reduction of crimes and recidivism. Are there better correction methods in developed countries?

In countries such as the United States of America (USA), there are two types of constitutions; federal and state constitutions. Therefore, in addition to the similarities, there should be significant differences in the correction agencies and methods in the USA. Therefore, it was decided to perform a study to identify post-conviction correction methods and types available in Sri Lanka and to compare those with the USA. The objectives of this study were to describe and examine the post-conviction correction agencies and methods available in Sri Lanka, their contribution to the rehabilitation of the convicts and to compare those with the USA.

\section{Literature review}

When the history of the correction methods of Sri Lanka is considered, it extends up to the inception of the mankind of Sri Lanka. In ancient Sri Lankan kingdoms, harsh punishment as well as correctional procedures had been in force and administered by the King himself and Adigars. However, in 1802, the Governor of Sri Lanka, Sir Fredrick North banned 
the then existing barbarous methods of punishments and introduced the death penalty by hanging. ${ }^{[1]}$ In 1844, the first prison ordinance, "An Ordinance for the better regulation of Prisons Act No. 18" was enacted and established the Welikada Prison. In 1905, The Department of Prisons was separated from the Department of Police as an independent Department. In 1990, a Rehabilitation Centre for inmates convicted on charges of drug addiction was established in Navodawa. In 2009, the Remand Prison of Vavuniya was established. In 2014, the Prison "Welfare Officer" rank was changed to "Rehabilitation Officer". ${ }^{[2]}$

The development of the post-conviction correction methods of the United States came in three major stages. According to Rothman (2002), during the 'Jacksonian Era' (1828-1865), all offenders (100\%) were sentenced to prison and $100 \%$ were under the supervision of prison. ${ }^{[3]}$ According to Christianson (1998), during the 'Progressive era' (1865-1920), new mechanisms such as parole, probation, and indeterminate sentencing were introduced and the number of convictions to the prisons was reduced to $50 \%$ and all of them $(100 \%)$ were under the supervision of prison. ${ }^{[4]}$ According to Jacob (1980), during the 'Civil rights era', the supervised release from prisons and sentencing guidelines were introduced and expected $0 \%$ should be in prison and $100 \%$ under the prison supervision. ${ }^{[5]}$ However, Since 1973, the number of incarcerated prisoners in the USA has increased five-fold and has the highest documented incarceration rate in the world (450/100,000 population). ${ }^{[6]}$

\section{Methodology}

A descriptive cross-sectional study based on latest secondary data on the post-convicts of Sri Lanka in 2016 published by Statistics Division of Prison Headquarters in the year 2017 ${ }^{[7]}$ and other relevant secondary data published by police, probation, judicial, correction etc was conducted. The data were collected on data collection sheets regarding post-conviction non-imprisonment and imprisonment correction methods. Regarding the post-conviction imprisonment correction methods; the demographic factors of the prisoners, types of offences committed, the types of court that admit the prisoners to prisons, the types of direct admission institutions of prison, the correction methods available in prisons, the methods of release and other rehabilitation procedures conducted in the prisons. The anonymous data were analyzed using the IBM SPSS 19.

\section{Results}

There were five methods of post-conviction corrections available. Of them, four were nonimprisonment correction methods; (1) 'Suspension of the sentences of imprisonment', (2) 'Supervision of Island reconvicted criminals (IRC)', (3) 'Probation' and (4) 'Intermediate sanctions. The fifth post-conviction method was 'Imprisonment'.

The first type of post-conviction non-imprisonment correction method is 'Suspension of the sentence of imprisonment'. They are granted only for the offenders who have no previous imprisonments. ${ }^{[8]}$ However, secondary data were not published in 2016.

The second type of post-conviction nonimprisonment correction was the 'Supervision of Island reconvicted criminals (IRC)' by police. Following three significant convictions, the police registers them as 'IRC' and are periodically supervised. There were 4462 registered criminals in 2014. ${ }^{[9]}$ According to the Colombo Crimes Division (CCD), in 2016, the total registered IRCs have been increased to 43,929 and of that number 973 are females. ${ }^{[10]}$

The third type of post-conviction non-imprisonment method of correction was the 'Probation' and there were two types; 'Probation orders' and 'Probation hostels with certified schools' for the minor offenders of 12-16 years of age. The certified schools are at Hikkaduwa, Makola, Jaffna, Kappetipola, Ranmuthugala and Madatugama. The numbers of minor offenders granted certified schools were 466 in 2016. ${ }^{[11]}$ However, the number of probation orders granted were not published in 2016.

The fourth type of post-correction nonimprisonment correction method was 'Intermediate sanctions'. Some post-convicted criminals are not sent to prison but are ordered 'Community-based correction (CBC) orders' to do community work or 'Order to pay fines, compensation or restitution'. The number of convicts who were granted such intermediate sanctions in 2016 was $14086 . .^{[12]}$ The non-imprisonment correction methods available for convicts and their types are shown in Table 1.

The other post-conviction correction method available was the 'Imprisonment'. According to the Prison statistics of Sri Lanka, issued in 2017, the number of convicted prisoners in Sri Lankan prisons in 2016 was $24,060 .{ }^{[6]}$ Of them, 96\% $(n=23,165)$ were males and remaining $(n=895)$ were females. When the demographic factors of prisoners were considered, the majority of the convicted criminals belonged to 23-39 years of age $(n=14,207,59 \%)$. When the literacy was considered, the majority had studied less than grade 8 standard $(n=20,425,85 \%)$. According to religion, the majority were Buddhists (51\%). Majority of the prisoners (76\%) were married. A significant number had committed narcotic drug offences $(44 \%)$. Majority of 
admissions of convicted prisoners to prisons was from Magistrate courts $(\mathrm{n}=21,647,90 \%){ }^{[7]}$

Table 1. The post-conviction non-imprisonment correction methods in 2016

\begin{tabular}{|c|c|c|}
\hline $\begin{array}{l}\text { Methods of } \\
\text { correction }\end{array}$ & $\begin{array}{l}\text { Types of } \\
\text { correction }\end{array}$ & $\mathbf{n}$ \\
\hline $\begin{array}{l}\text { (1) Suspended } \\
\text { sentences }\end{array}$ & $\begin{array}{l}\text { Suspension } \\
\text { of the } \\
\text { sentence }\end{array}$ & $\begin{array}{r}\text { Not } \\
\text { published }\end{array}$ \\
\hline $\begin{array}{l}\text { (2) Supervision of } \\
\text { IRC }\end{array}$ & $\begin{array}{l}\text { Periodical } \\
\text { supervision }\end{array}$ & 43,929 \\
\hline \multirow[t]{2}{*}{ (3) Probation } & $\begin{array}{l}\text { Probation } \\
\text { orders }\end{array}$ & $\begin{array}{r}\text { Not } \\
\text { published }\end{array}$ \\
\hline & $\begin{array}{l}\text { Probation } \\
\text { hostels \& } \\
\text { certified } \\
\text { schools for } \\
\text { minor } \\
\text { offenders } \\
\text { (12-16 } \\
\text { years) }\end{array}$ & 466 \\
\hline \multirow[t]{2}{*}{$\begin{array}{l}\text { (4) Intermediate } \\
\text { sanctions }\end{array}$} & $\mathrm{CBC}$ orders & 14,086 \\
\hline & Order to pay & $\begin{array}{r}\text { Not } \\
\text { published }\end{array}$ \\
\hline
\end{tabular}

Of the 24,060 direct admissions, based on their behaviour within the prison, 456 were sent to the open prison camp in Pallekele and 588 to work camps in Meethirigala $(n=13)$, Homagama $(n=94)$, Weeravila $(\mathrm{n}=253)$, Anuradhapura $(\mathrm{n}=130)$, Kadurugasara $(n=60)$ and Hangilipola $(n=38)$. Based on the offence committed, 180 convicts were serving death sentence and 23 were serving life imprisonment. ${ }^{[7]}$

Another method of corrections in imprisonment is 'Rehabilitation'. Almost all prisoners were given some kind of rehabilitation. For further rehabilitation of prisoners, there were 'Release methods' ( $\mathrm{n}=4984,21 \%)$; 'Work release scheme', 'Home leave scheme' and 'License scheme (parole)' ("Prisons statistics of Sri Lanka", 2017). ${ }^{[6]}$ Table 2 shows the post-conviction correction methods available in prisons of Sri Lanka in 2016.

In 2016, 30,811 were discharged. The 'Final discharge" was available on bail $(\mathrm{n}=74)$, after payment of fines $(n=13,003)$, on pardon $(n=1879)$ and after serving the sentence $(n=15,855) .{ }^{[7]}$

Table 2: The post-conviction imprisonment correction methods of Sri Lanka in 2016

\begin{tabular}{lr}
\hline Types of correction & $\begin{array}{r}\text { N=24,060 } \\
\mathbf{n}(\%)\end{array}$ \\
\hline (1) Closed prisons & $12,464(52 \%)$ \\
(2) Remand prison & $11,582(48 \%)$ \\
(a) Open prison camp & 456 \\
(b) Work camps & 588 \\
(c) Death sentence & 180 \\
(d) Life imprisonment & 23 \\
(3) Training school for youthful & $14(0.01 \%)$ \\
offenders (16-22 y) & All \\
(4) Rehabilitation & $4984(21 \%)$ \\
(5) Release methods & $4165(17 \%)$ \\
(i) Work release scheme & $589(03 \%)$ \\
(ii) Home Leave scheme & $230(01 \%)$ \\
(iii) license scheme (parole)
\end{tabular}

\section{Discussion}

There are correction methods that apply to preconviction and post-conviction offenders, however, this study considered only the post-conviction correction methods. According to this study, in 2016, there were five types of post-conviction correction methods in Sri Lanka. Further, these could be non-imprisonment or imprisonment correction methods. Of them, four were postconviction non-imprisonment correction methods such as (1) Suspension of the sentences of imprisonment, (2) Supervision of Island convicted criminals (IRC), (3) Probation and (4) Intermediate sanctions. The fifth type was post-conviction 'Imprisonment'.

'Suspension of the sentences of imprisonment' is a post-conviction non-imprisonment correction method available in Sri Lanka. It was introduced in 1972. These are imposed on offenders whose sentences are not exceeding two years. The period of suspension should be more than five years and fingerprints are taken. If violated, the punishment will be reactivated. ${ }^{[8]}$ However, the number of suspended sentences ordered in 2016 was not published. On the other hand, the imprisonment is also an effective correctional technique and there is no scientific rationale in the fashionable argument that prisons do not correct and that, therefore, they should be abolished ${ }^{[13]}$ or so modified that they become hospitals rather than places of punishment. ${ }^{[14]}$

'Supervision of the Island reconvicted criminals (IRC)' by police is another post-conviction nonimprisonment correction method. When more than three (3) significant offences are committed, such offenders are registered as 'IRC' by the police and 
are graded into 3 groups. If IRC grade A, they are monitored weekly by police. If IRC grade B, they are monitored every month and if grade $\mathrm{C}$ in every 3 months. They can change their place permanently after obtaining the permission from the police and has to register with the new police. There were 4462 registered criminals in 2014 (Rohana A, 2014). However, 2016 there were 43,929. ${ }^{[10]}$ Similarly, in the USA, the sex offenders are registered and are supervised. In 2016, there were a total of 861,837 sex offenders registered and supervised in the USA. ${ }^{[15]}$

The third type of post-conviction non-imprisonment correction is 'Probation' and there were two types; 'Probation orders' and 'Probation hostels with certified schools for 12-16 years minor offenders'. 'Probation order' means the rehabilitation of an offender without subjecting to institutionalization, fine or other punishments. ${ }^{[16]}$ In Sri Lanka, the Probation system was introduced in the 1930s. In 1944, on the Probation Ordinance No. 22, the probation became a branch of the Prison Department. In 1956, it was separated from the prison and formed the Department of Probation and Child Care Services (DPCCS). ${ }^{[16]}$ In 1987, with the 13th amendment to the Constitution, the Probation and Child Care Service was devolved to the Provincial Councils. Then the Assistant Commissioner was abolished and Provincial commissioners of Probation and Child Care were introduced and the Probation Officers (PO) were brought under their supervision. Since 2010, probation functions under the Ministry of Child Development and Women's Affairs. ${ }^{[16]}$ In minor offences, the punishment is suspended and 'Probation orders' are given for 1-3 years. Another advantage is that their fingerprints are not taken. However, if violates, the court punishment will be reactivated. Person has to follow certain Courtordered rules such as meeting with their Probation Officer (PO) with 24 hours of the order and one or more occasions a month, avoiding certain people and places, cannot change the employment or place of sleep without approval of $\mathrm{PO}$, obey the directions of PO such as refraining from using illegal drugs or excessive alcohol etc. ${ }^{[16]}$

Minor offenders (12-16 years) are kept separately in probation, otherwise, children learn the subcultures from the adult criminals. In Sri Lanka, minor offenders are sent to 'Probation hostels with certified schools'. ${ }^{[17]}$ Such schools are located in Hikkaduwa, Makola, Jaffna, Kappetipola etc. Sri Lanka became a signatory to the Convention on the Rights of the Child (CRC) in 1991, ratified in 1992 and therefore, in 1999 the Department of Probation created a new post called Child Rights Promotion Officer (CRPO) and attached them to the District and Divisional Secretariats. ${ }^{[13]}$ In 1990, According to
Jayasundara MW (1992), there had been 14,000 convicts under probation. ${ }^{[18]}$ In 2005 , there had been 575 convicts on probation. ${ }^{[19]}$ However, the numbers of convicts on probation in 2016 was not published (Table 1). Similarly, in America, the U.S. Probation and Pretrial Services System is the community corrections arm of the federal judiciary. It is found in all 94 federal District Courts (DC) and uses at both the pretrial and post-conviction stages. The probation and Pretrial service officers are considered the "eyes and ears" of the federal Courts and they investigate and supervise persons convicted of federal crimes. ${ }^{[20]}$

Until 1825, juvenile offenders in the USA were housed together with adult criminals. The New York Society for Prevention of Pauperism wisely considered the feasibility of providing a separate institution for the reformation of juvenile offenders, later established as 'New York House of Refuge'. [21] Furthermore, old US public health surveys demonstrated that number of these juvenile inmates are under average in mental development or suffer from some form of psychotic disturbances. The efficiency of correctional methods as an alternative to imprisonment need to be evaluated and the random group design, matched group design, prediction analysis and prediction research have been suggested as research models for this purpose. ${ }^{[22]}$

The fourth post-conviction non-imprisonment correction method is the 'Intermediate sanctions'. The whole idea behind it is to find something inbetween probation and prison. Probation usually is just telling the offender to go "handle their problems" while intermediate sanctions represent an attempt to tailor the punishment to the criminal. The methods of intermediate sanctions available in 2016 in Sri Lanka were 'Order to pay Fines, compensation or restitution' and 'Community-based correction order'.

Sometimes, the convicts are asked to pay 'Fines' to the government. Some convicts are asked to pay 'Compensation' to the victim. ${ }^{[23]}$ Restitution involves the payment of money for restoring the stolen property. ${ }^{[2]}$ The number of such convicts in 2016 was not published (Table 1). However, in Sri Lanka, the majority $(\mathrm{n}=12,670,53 \%)$ of postconvicted prisoners were 'Fine defaulters'. ${ }^{[7]}$

Another intermediate sanction is 'Community-based correction order'. In fact, community-based correction has been practised as an effective method of reformation during medieval Sri Lankan kingdoms as well. Mihinthale tablet of King Mahinda IV declared that in lieu of an assessed fine, offenders could be made to perform various duties like construction and repairing reservoirs. King 
Bhatika Tissa ordered the cleaning of the royal courtyard as an alternative punishment for a group of persons who were unable to pay the fine for consuming beef. ${ }^{[25]}$

In Sri Lanka, the community service orders were first introduced in 1974. In 1999, a new act was enacted as "Community-based Corrections Act No. 46". ${ }^{26]}$ These orders are offered when the term of imprisonment exceeds two years. For example, when a person is unable to pay a fine, compensation or restitution, a community-based correction order is given. Before that, a 'Pre-sentence report' is sought from the commissioner of corrections. Then the consent of the offender is taken and the conditions of the order are provided in a prescribed form. The convict has to perform unpaid community service at a named place, for example, cleaning a park, repairing a house, picking up litter, etc. ${ }^{[27]}$ If a correction order is offered, the offender has to report to the community correction centre of that judicial area. For a week, the offender has to do a minimum of unpaid work for 10 to 24 hours. The duration of the service should not be ordered more than one year from magistrate courts and not more than 3 years from High Court. ${ }^{[26]}$ The number of community service orders offered in 2016 was 14,086 (Table 1). In the USA, in addition to the above methods, many more intermediate sanctions are used. One method is 'Intensive Supervised Probation' and it allows more monitoring and supervision. The 'Boot Camps' involve military-like training. 'Shock Incarceration' is a split-sentence to remand or prison for a short time (usually 30 days) and then release the inmate to the community under probation where the inmate does not know it in advance. 'Halfway Houses' are a middle point between prison and full release to the community. 'Home Confinement' is the use of house arrest but is often combined with electronic ankle bracelets that "track" the offender's movements, and is a rather cost-effective method. ${ }^{[28]}$

When post-conviction 'Imprisonment' correction methods are considered, there were three types; (1) Closed prisons, (2) Remand prisons and (3) Training schools for youthful offenders (16-22 years). The number of convicted prisoners admitted in Sri Lankan prisons in 2016 was 24,060 (115/100,000 population) and it was almost similar $(24,086)$ to the previous year, 2015. ${ }^{[29]}$ The USA correctional authorities had 15,05,397 (1.51 million) prisoners in 2016 and there had been 450/100,000 US population. ${ }^{[30]}$ Therefore, the rate of imprisonment of USA is about 4 times higher than Sri Lanka.

When the demographic factors of post-conviction imprisonment of Sri Lanka are considered, 96\% $(n=23,165)$ of prisoners were males. The majority $(\mathrm{n}=14,207,59 \%)$ were young adults between 23 to 39 years of age. When the literacy was considered, the majority $(n=20,425,85 \%)$ had studied less than grade 8 standard. Though the majority were Buddhists (51\%), when compared with the percentage of the Buddhists in the national population $(70.2 \%)$, it is low. ${ }^{[31]}$ When the marital status is considered, the majority $(76 \%)$ of the convicts were married. A significant number had committed narcotic drug offences (44\%). The prisoners were categorized into three groups; firsttime offenders reconvicts with two convictions and recidivists with more than two convictions. Therefore, young, married male, Buddhists who have less literacy were the vulnerable group. When the sex of the convicts was compared, $96 \%$ $(n=23,165)$ of prisoners in Sri Lanka were males while in the USA it was $93 \% .^{[30]}$

The ultimate objective of the imprisonment is to rehabilitate and reform the convicted offenders and reintegrate them to society. Many progressive measures have been adopted to achieve this objective. There were three basic post-conviction imprisonment correction types; (1) 'Remand prisons', (2) 'Closed prisons' and (3) 'Training schools for youth offenders of 16-22 years (TSYO)'.

The 'Remand prisons' are meant for pre-conviction detentions awaiting trial or bail. However, in Sri Lanka, in addition to them, the post-convicted prisoners are also located in remand prisons for short terms. Therefore, the pre-convicted offenders should be kept separate according to their type of crime committed such as violent, sexual assault, property, organized and drug criminals, etc., otherwise they learn those subcultures while in the remand prison from the post-convicted criminals. However, such separation is not strictly done in Sri Lankan remand prisons. In Sri Lanka, by 2016 there were 19 remand prisons and $48 \%(n=11,582)$ of the post-convicted prisoners were in remand prisons. ${ }^{[29]}$

The second post-conviction imprisonment type is 'Closed prisons'. In closed prisons, there is a perimeter wall and the prisoners are held under maximum security conditions. Their inmates should also be kept separate according to their crime committed, otherwise they learn those subcultures while in prison. Eg. Violent criminals, sexual assault criminals, property criminals, organized criminals, drug criminals, etc. In Sri Lanka, there are 3 closed prisons; Welikada, Bogambara, and Mahara. ${ }^{[29]}$

Among the closed prisoners, there are 4 sub categories of corrections. Of the prisoners who had been sentenced for less than 5 years, based on their behaviour within the prison, some are sent to a large 'Open prison camp' and some to medium size 'Work camps' $(\mathrm{n}=588) .{ }^{[29]}$ 
(a) The open prison camp was first established in 1951 in Sri Lanka. Prisoners with good conduct, who would have served one-fourth of their sentence and with at least two years more to serve are selected. e.g. Pallekelle open camp. The objective is to rehabilitate and facilitate the re-integration to the society. The main guiding principle is trust. Families are encouraged to meet inmates often and such visits are not supervised by prison officers. They can build relationships with those in the free community and also encourage to participate in community projects on an entirely voluntary basis. ${ }^{[29]}$

(b) The 'Work Camps' are open institutions with no boundary walls. First-time offenders with less than two-year sentence offenders are transferred to these work camps. It is promoted due to the presence of a large number of first-time offenders with short prison terms and they should be kept away from contamination by hard-core criminals. These prisons have minimum-security conditions and the objective is the rehabilitation. ${ }^{[32]}$

Based on the severity of the offence committed, some serve 'life imprisonment' and some serve 'Death sentence' or 'Life in presentment'.

(c) Some had been serving life imprisonment $(n=23)$.

(d) Some were serving 'Death sentence' or 'Life in presentment' $(n=180)$. The prisoners on 'Death sentence' were under appeal awaiting execution of final decision for commutation of execution by hanging. However, the number executed was zero in 2016. In the USA, there had been 20 executions by lethal injection using a mixture of barbiturate, paralytic, and potassium. ${ }^{[33]}$

The third method of post-conviction imprisonment correction type is the "Training School for youthful Offenders" (TSYO) in Watarake, Sri Lanka for 1622 years offenders. The youthful offenders who were at Wathupitiwala were shifted to Pallansena in 1997, and then to Ambepussa in 2009, and to Watareka in 2015. It had 14 admissions in 2016. ${ }^{[29]}$

There are two other correction methods that are common to all the post-convicted prisoners; (i) Rehabilitation and (ii) Release methods

(i) All the post-convicted prisoners are provided with different levels of rehabilitation. It has vocational training, farming and religious activities. Every convicted prisoner sentenced to rigorous imprisonment is required to work for eight hours a day. Therefore, carpentry, tailoring, laundry, motor mechanism, printing, bread making, weaving, knitting, masonry, soap making, mat making, brush making, polishing, and the manufacture of coir goods are being taught. They do agriculture and animal husbandry. Prisoners have to attend education, recreation and religious activities and almost all are given some kind of rehabilitation. The value of industrial and agricultural output in 2016 was Rs. $153,709,118.00$. Of them, bakery products gave $46 \%$ of the income. ${ }^{[29]}$

(ii) Another common correction method for postconvicted prisoners is the introduction of different 'Release methods'. With these methods, $21 \%$ were released in 2016. The types were; Work release scheme, Home Leave scheme and License scheme (Paroles).

(a) In 'Work release scheme', prisoners are allowed to get themselves employed in the open community unescorted during the day and return to a work release centre or a prison for the night. In 2016, 4,165 were released on work release scheme.

(b) In 'Home leave scheme', long-term prisoners are permitted to visit their homes unescorted for a maximum period of 7 days at a time, once in 6 months. In 2016, it was granted for 589 prisoners. It was introduced in 1974 to Sri Lanka. The purpose is to facilitate the re-integration in the society and family on his return. ${ }^{[29]}$

(c) The release of prisoners on 'License scheme (Parole)' was introduced in 1970. A scheme under which certain categories of prisoners are conditionally released from prison prematurely under the supervision of prison "Rehabilitation officers (ROs)" (previously named as welfare officers). In 2016, this was granted for 230 prisoners. The prisoners who have been sentenced to four years or more and who have completed half their sentence and the prisoners who have served six years of their sentence and the prisoners who have served five years of their sentence with one year in an open prison camp becomes eligible for parole. A social report with a plan of his rehabilitation in the community is prepared by ROs and submits to the 'License board'. In the history of parole in Sri Lanka, less than 50 prisoners have violated their conditions of release and have had their license revoked. ${ }^{[26]}$ Parole has three-fold purposes. Firstly, it assists the parolee to adjust to the normal life and helps to re-integrate to the community and with the help of RO, a parolee may obtain help with problems concerning employment, residence, finances, or other personal problems. Secondly, it prevents parolee committing new crimes. Thirdly, it prevents needless imprisonments of those who are not likely to commit further crimes. The U.S. Parole Commission may grant parole if they are satisfied on few conditions such as the inmate has substantially observed the rules of the institution, the release would not depreciate the seriousness of the offence 
or promote disrespect for the law and the release would not jeopardize the public welfare. ${ }^{[34]}$ The grant or deny is at the discretion of the 'Parole board'. The released inmate is placed under the supervision of a 'Parole officer' for a certain amount of time after being so released.

(d) Finally, the post-convicted prisoners are 'Discharged' ( $n=30,811)$ on bail, paying fines, on pardon or after serving the sentence. Then the prisoner is registered and the notification is done. Pardon was granted for 1879 in 2016 and of them, 600 prisoners were released on the Independence Day. ${ }^{[29]}$ Final discharge after serving the sentence is the end of the prison life.

\section{Conclusions}

There were five types of post-conviction correction methods. Four were non-imprisonment corrections; 'Suspension of the sentences of imprisonment', supervision of 'Island reconvicted criminals (IRC)', 'Probation' and 'Intermediate sanctions'. The fifth type is imprisonment.

Suspended sentences are granted for first-timers. When more than three convictions, they are registered as IRC and are supervised periodically. In the USA, the sex offenders are registered and supervised. Under probation, 'Probation orders' and for 12-16 years minor offenders the 'Probation hostels and certified schools' are available. In the USA 'U.S. Probation and Pre-trial Services System' is available. Under 'Intermediate sanctions'; 'Community-based correction order' and 'Order to pay fines, compensation or restitution' are considered. The majority of post-convicted prisoners in 2016 were 'Fine defaulters. In addition to those intermediate sanctions, in the USA, 'Intensive Supervised Probation', 'Boot Camps' 'Shock Incarceration' 'Halfway Houses' and 'Home Confinement' are available.

The post-convicted imprisonment has three types of correction methods; remand prison, closed prison and Training school for youth offenders (TSYO). Of them, based on their behaviour some prisoners are sent to large open prison camps or moderate size work camps. Based on the offence committed, some prisoners were serving death sentence and some were serving life imprisonment. Two more correction methods common to all prisoners are 'Rehabilitation' and 'Release'. Almost all the convicts were given some kind of rehabilitation at different levels. The different release methods available for the prisoners are 'Work release scheme', 'Home leave scheme', 'License scheme (parole)' and final 'Discharge'.

Further, the rate of imprisonment in Sri Lanka $(115 / 100,000)$ is about 4 times lesser than the USA
(450/100,000). In Sri Lanka, the majority of the post-convicted prisoners were married, young adult, Buddhist, males who have studied less than grade 8 and they do not have the capacity to pay fines, compensations or restitution. Hence, imposing of large fines may further increase the number of prisoners and the burden to the government. Therefore, the future development and modification of the criminal justice system should be evidencebased.

\section{Acknowledgements}

No funding. I like to thank the statistics division of the prisons headquarters and other relevant institutions for publishing secondary data with public access

\section{References}

1. Newman, G. 1978. The Punishment Response. New York: Lippincott.

2. Department of Prison. from http://www.prisons.gov.lk/Institution/ institutions _all_ english.html. Retrieved on 2018, May $0 \overline{1}$

3. Rothman DJ. Conscience and Convenience: The Asylum and Its Alternatives in Progressive America. Transaction: New Youk; 2002

4. Christianson S. With Liberty for Some: 500 Years of Imprisonment in America. Boston: Northeastern University Press, ; 1998

5. Jacobs, JB. The Prisoners' Rights Movement and Its Impacts, 1960-80, Crime and Justice. 1980:2(1):429-70. Doi.org/10.1086/449074

6. Weiss DB, MacKenzie DL. A Global Perspective on Incarceration: How an International Focus Can Help the United States Reconsider Its Incarceration Rates. Victims and Offenders. 2010;5(3):268-82. DOI: $10.1080 / 15564886.2010 .485910$

7. Prisons statistics of Sri Lanka (2017). Statistics Department, Prisons Headquarters. Colombo $09 . \quad$ Vol. 36. www.prisons.gov.lk/Statistics/Statistics2017.pdf

8. Section 303, Suspended sentence of imprisonment. Code of Criminal Procedure, Act No 15 (1979). Parliament of the Democratic socialist republic of Sri Lanka. https://www.lawnet.gov.lk/1946/12/31/codeof-criminal-procedure-amendment-17/

9. Rohana A. 4462 registered criminals in Sri Lanka in 2014. http://www.hirunews.lk/ goldfmnews/74873/ 4462-registered-criminalsin-sri-lanka

10. 973 female IRCs in the country. http://www.infolanka.com/news/2016/july/inde $\mathrm{x} 43 . \mathrm{html}$

11. Admissions to Certified Schools from 2013 to 2016. www.probation.gov.lk /documents /downloads /Annual \% 20Bulletin\%202.pdf. 
12. Performance Report, Department Of Community Based Corrections, 2016 since January to December. www.parliament.lk/performance-reportdepartment-of-community-based-correction.

13. Martin JB, Break down the valls (1954).

14. Karpman. Criminality, Insanity and the Law. Journal of Criminal Law and Criminology. 1949;584

15. Map of Registered Sex Offenders in the United States (2018). www.missingkids.com/ content/dam/ncmec/en us/document/ sexoffendersmap.pdf

16. Annual performance report, DPCCS", 2015. Department of probation and child care services. www.parliament.lk/performancereport-department-of-probation-child-careservice.

17. Probation of Offenders Act No. 10 (1948). http://www.lawnet.lk/process.php?st= 1981Y 3V34C \& hword =" \&path $=5$

18. Jayasundara MW (1992). Community-based correction in Sri Lanka: the Samodaya service. summit.sfu.ca/system/files/iritems 1/3765/b142 60591.pdf

19. Abeysirigunawardene J. (2000), overcrowded prisons and present practices and experience in relation to community-based alternatives to incarceration.

www.unafei.or.jp/english/pdf/RS_No79/No79 32PA_Abeysirigunawardana.pdf

20. U.S. Probation and Pretrial Services System (2018).

https://en.wikipedia.org/wiki/U.S._Probation_ and_Pretrial_Services_System

21. Treadway $\bar{W} L$. Correctional Methods and Reformation of Juvenile Delinquents. Public health reports. 1919;34(37):2062-3

22. Bell JA. Australian and New Zealand Journal of criminology. 1974;7(1):55 - 2

23. Section 17 (4), Payment of costs and compensation upon conviction. Code of Criminal Procedure, Act No 15 (1979). Parliament of the Democratic socialist republic of Sri Lanka.

24. Section 306 (4), Power of court to permit conditional release of offenders. Code of
Criminal Procedure, Act No 15 (1979). Parliament of the Democratic socialist republic of Sri Lanka.

25. Peiris K. Crime and punishment in ancient and medieval Sri Lanka. The Island Saturday magazine 2009 Jan 10. Available at http://www.island.lk/2009/01/10/satmag4.html. Accessed 26 November 2018.

26. Community-based Corrections Act (No. 46 of 1999) - $\quad$ Sect 5. http://www.commonlii.org/lk/legis/num_ act/cbca 46o1999345/s5.html

27. Section 18. Community service orders, Code of Criminal Procedure, Act No 15 (1979). Parliament of the Democratic socialist republic of Sri Lanka.

28. Latessa Edward J. (2018). Overview of correctional programmes in the USA. 36-47. https://pdfs.semanticscholar.org/81de/152cc2a 6194efd821c69a3729288b6e14404.pd

29. Prisons statistics of Sri Lanka (2017). Statistical division, prison headquarters, Colombo 09, Sri Lanka. 36, ISBN: 978-955-9342-33-5. www.prisons.gov.lk/Statistics/Statistics2016.pdf

30. Prisoners in USA. (2016), Bureau of Justice, USA, https://www.bjs.gov/index.cfm?ty= pbdetail\&iid

31. Department of Census and Statistics (2011), The Census of Population and Housing of Sri Lanka-2011. http://www.statistics.gov.lk/PopHouSat/CPH20 11/

32. Kuruppu G. (2000). Current issues in correctional treatment and effective countermeasures. www.unafei.or.jp/English/ pdf/RS_No57/No57_30PA_Kuruppe.pdf

33. List of offenders executed in the United States in $2016 \quad$ (2018). https://en.wikipedia.org/wiki/List_of offenders_executed_in_the_United_States_in 2016

34. US parole commission (USPC) Rules and Procedures manual - Department of Justice. https://www.justice.gov/sites/default/files/uspc /legacy/2010/.../uspc-manual111507.pdf 